DOI: http://dx.doi.org/10.18524/1810-4215.2018.31.145374

\title{
ON THE IRREGULAR VARIATIONS IN THE LIGHT CURVES OF RY Vul
}

\author{
S.N. Udovichenko, L.E. Keir \\ Astronomical Observatory, Odessa National University, \\ Odessa, Ukraine, udovich222@ukr.net
}

ABSTRACT. In the Astronomical observatory of the Odesa National University traditionally study variable stars of different types: pulsating, double, irregular et al. By photometric observations it is possible to set the type of variable star, period of the brightness changes, spectral class, to estimate the temperature of surface. For observations variable stars there was the chosen area of star sky from by two stars Y Vul and RY Vul in the distance not more than 15 angular minutes (angular size of one frame). For these stars was got more than 5900 images during 56 nights during observant seasons 2011-2017. For all observations were got the curves of light variations. Results are for variable star Y Vul (type RR Lyr) published separately, and in this publication we bring results over of observation for star RY Vul. The star RY Vul according General Catalogue of Variable Star (GCVS) is RR Lyr variable, but period and initial epoch are unknown. To determine these parameters the photometric observations during several seasons in 2011-2017 of the variable star RY Vul on the Astronomical station near Odessa have been carried out. The 48-cm telescope reflector AZT-3 equipped with CCD photometer was used. The light curves in $\mathrm{V}$ and $\mathrm{R}$ band were obtained and analyzed. It turned out that the light curves of the star is fully irregular. Therefore, the variable star RY Vul should be attribute to type "irregular variables".

Keywords: Stars: oscillations - stars; variables: stars: individual: RY Vul.

АБСТРАКТ. В Астрономічній обсерваторії Одеського Національного університету традиційно вивчають змінні зорі різних типів: пульсуючі, подвійні, нерегулярні та інші. Шляхом фотометричних спостережень можна встановити тип змінної зорі, період зміни блиску, спектральний клас, оцінити температуру поверхні. Для спостережень змінних зір була вибрана ділянка зоряного неба 3 двома зорями $\mathrm{Y}$ Vul та RY Vul на відстані не більше 15 кутових хвилин (кутовий розмір одного кадру). Для цих зір було отримано більше ніж 5900 експозицій протягом 56 ночей впродовж спостережних сезонів 2011-2017 років. Для всіх спостережень були отримані криві блиску. Результати для змінної зорі Y Vul (тип RR Lyr) опубліковані окремо, а в цій публікації ми приводимо результати спостережень блиску для зорі RY Vul. Зоря RY Vul згідно Загального Каталогу Змінних Зір (ЗК33) $є$ змінною типу RR Lyr, але iii період та початкова епоха невідомі. Щоб визначити ці параметри були проведені фотометричні спостереження змінної зорі RY Vul на астрономічній станції біля Одеси протягом декількох сезонів. Всі спостереження були проведені за допомогою 48-см телескопа-рефлектора АЗТ-3, оснащеного ПЗ3 фотометром 3 охолодженям елементом Пельт'є та стабілізацією температури. Криві блиску були отримані та проаналізовані в смугах V i R. Обробка зоряних зображень була виконана за допомогою програми MUNIPACK (Motl, 2009-17). В цій програмі для калібрування зоряних ПЗ3 кадрів використовуються зображення темнового кадру та плоского поля. Виявилось, що криві блиску зорі повністю нерегулярні протягом всіх років спостережень. Приводяться криві блиску, частотний аналіз фотометричних спостережень. Висновок: змінну зорю RY Vul необхідно віднести до типу «нерегулярні змінні зорі».

Ключові слова: Зорі: осциляції - зорі; змінні: зорі: індивідуально: RY Vul.

\section{Introduction}

RY Vul (AN 1907.0025, GSC 2126.00973), $\left(\alpha_{J 2000.0}=19^{h} 04^{m} 33.8^{s} ; \delta_{J 2000.0}=+24^{\circ} 46^{\prime} 25.0^{\prime \prime}\right)$ according GCVS is RR Lyr variable. The variability of the star was found by Parenago (1934). The finding chart for this star was published by Tsesevich and Kazanasmas, (1971). The star has been poorly investigated, only Steinbach H.M. reported that RY Vul was observed in August-September 2009 in 4 nights with a total amount of nearly 10 hours in Johnson V-Band. During that time the star showed no variability at all 


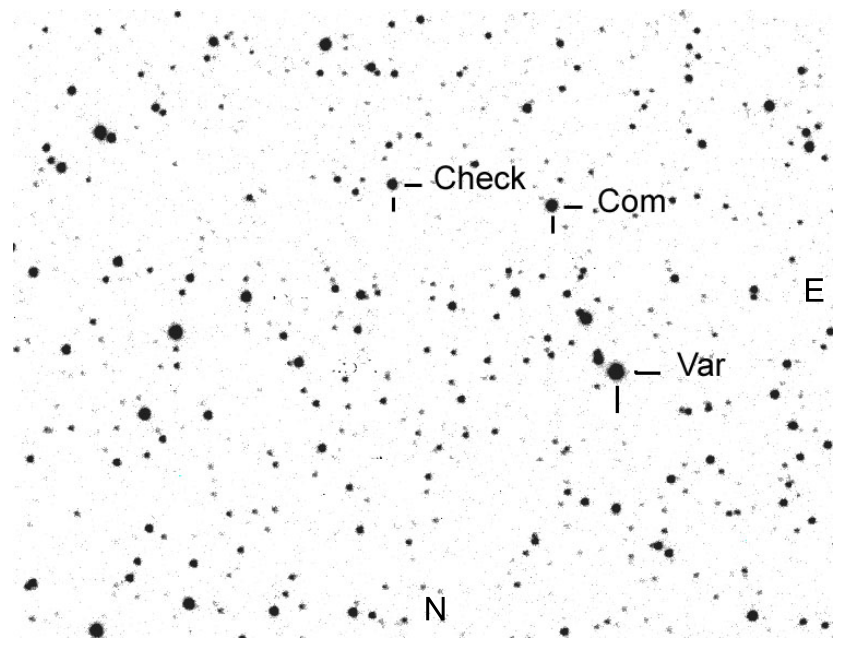

Figure 1: The finding chart RY Vul with the comparison and check stars marked.

but remained constant at $11.60^{m}$ in accordance with the value mentioned in the GSC. He drawn a conclusion that RY Vul obviously is not a variable star and should be discarded from the GCVS (Steinbach, 2010).

\section{Observations}

To study this phenomenon, we have to realize as much as possible observations of this star. The photometric CCD observations of RY Vul in Astronomical station near Odessa in observation season 2011, 2012, 2014, 2017 years have been carried out.

Two stars were chosen as comparison and check stars $\left(\operatorname{comp}=\mathrm{UCAC} 4\right.$ 1125-11260150, Vcomp $=13 .{ }^{m} 10$ (APASS, 2010), check=UCAC4 1125-11251433). The $48 \mathrm{~cm}$ reflector AZT-3 with the f/4.5 Newtonian focus and CCD photometer with chip Sony ICX429ALL (600x800 pixels), equipped with V and R filters, Peltier cooler were used (Udovichenko, 2012). The hermetic housing and thermoelectric (Peltier) cooler provide a temperature difference between the sensor CCD and the environment of about $-40^{\circ} \mathrm{C}$, and the temperature was supported by a constant. The exposure time for variable and comparison stars for the most part were chosen to exclude a saturation of frame. More then 5900 CCD frames were gathered during 56 nights.

The standard reductions of the CCD frames were carried out using the MUNIPACK (Motl, 2009-17) software. The procedures for the aperture photometry is composed of the dark-level and flat field corrections and determination of the instrumental magnitude and precision. The finding chart with comparison and check stars are shown in Fig. 1. The errors on individual data points vary between $0.005 \mathrm{mag}$ to $0.015 \mathrm{mag}$.

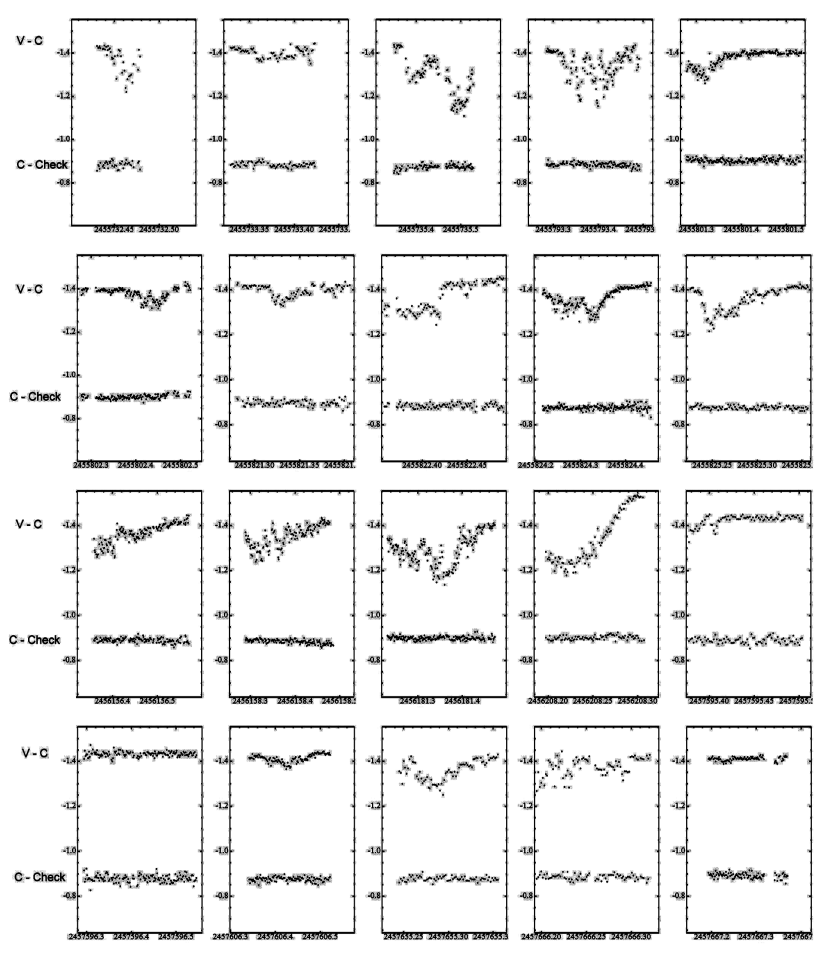

Figure 2: The differences V-C and C-Check vs HJD for the several nights observations.

\section{Analysis of data}

For all our observations of RY Vul were determined the difference magnitudes comparatively of variablecomparison star (V-C), and comparison-check star (CCheck). These differences for several nights are presented in Fig. 2.

These curves testify and show, that light of a star from night by the night changes nonperiodic, irregularity. Also the frequency analyses were performed using a package of computer programs with singlefrequency and multiple-frequency techniques by using utilize Fourier as well as multiple-least-squares algorithms (program Period04, Lenz and Breger, 2004). The frequency analyses for our observations and ASAS data (Pojmanski G., 2002) have not shown some the significant periods (Fig. 3). It is not considered the alliance peaks connected with periodicity of observations (multiple one days).

From catalogs XPM(Fedorov), NOMAD the star RY Vul has $\mathrm{B}-\mathrm{V}=1.2-1.44, \mathrm{~T}$ eff $=3831.8 \mathrm{~K}$ (Gaia) and concerns to late spectral classes K-M (VizieR, 2018).

Thus, the variable star RY Vul should not be discarded from the GCVS catalogue and should be ranked as type ISB: Rapid irregular variables of the intermediate and late spectral types F-M. 

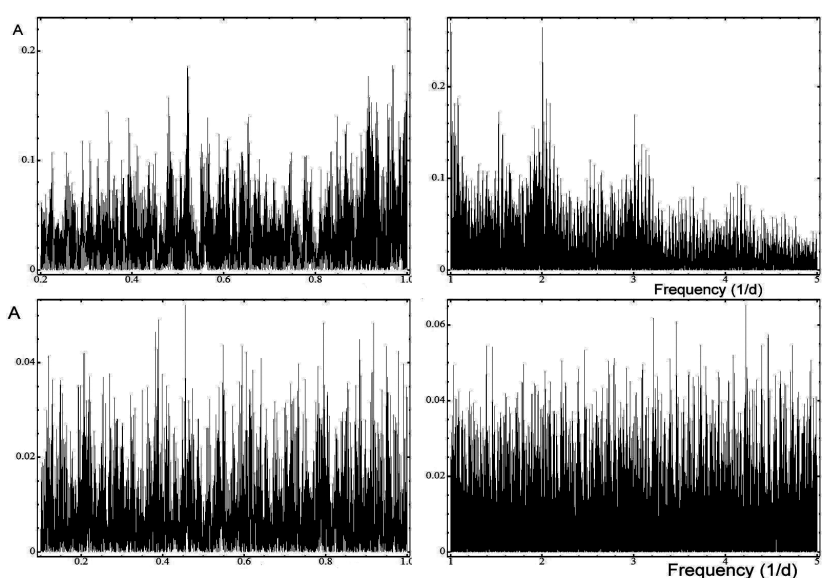

Figure 3: The Fourier amplitude spectrum for our observations (top) and ASAS data (bottom).

\section{References}

APASS, Star catalog: 2010, http://www.aavso.org Lenz P., Breger M.: 2004, Comm.in Asteroseismology 144, 41

Motl D.: 2009-17 http://sourceforge.net/projects/ c-munipack

Parenago P.: 1934, Perem. Zvezdy 4, 301.

Pojmanski G.: 2002, Acta Astronomica, 52, 397.

Samus N.N., Durlevich O.V., Kazarovets E.V., Kireeva N.N., Pastukhova E.N., Zharova A.V. et al.: 2011, General Catalogue of Variable Stars (GCVS database, Version 2011Jan).

Tsesevich V.P., Kazanasmas M.S.: 1971, Atlas of Finding Charts of Variable Stars, Moscow.

Steinbach H.M.: 2010, BAVSR 59, 5.

Udovichenko S.N.: 2012, Odessa Astron. Publ., 25, 32. VizieR: 2018, Online Data Catalog. — http://vizier.ustrasbg.fr 